Portland State University

PDXScholar

Winter 2008

\title{
It's an Emergency: The Portland State University Library Flood
}

Kristen Kern

Portland State University, kernk@pdx.edu

Follow this and additional works at: https://pdxscholar.library.pdx.edu/ulib_fac

Part of the Library and Information Science Commons

Let us know how access to this document benefits you.

\section{Citation Details}

Kern, Kris. "It's an Emergency: The Portland State University Library Flood." OLA Quarterly. Vol 14, no. 4 (Winter 2008): 11.

This Article is brought to you for free and open access. It has been accepted for inclusion in Library Faculty Publications and Presentations by an authorized administrator of PDXScholar. Please contact us if we can make this document more accessible: pdxscholar@pdx.edu. 


\section{It's an Emergency: The Portland State University Library Flood}

\author{
by Kristen Kern \\ Preservation Librarian, \\ Portland State University
}

O $\mathrm{n}$ the first of November, 2004, I arrived at work to find an alarming note on my desk. "Call Terry Rohe," then Acting Director of the Library, "immediately," it said, "it's an emergency." I called at once to learn that there was water pouring into the library's basement through the west wall. I walked quickly across the Park Blocks to the Branford P. Millar building - my office in Technical Services is located in another building - and once inside ran down the steps to see what had happened.

There was indeed water running down the wall, with an accumulation of one to two inches in the book stacks closest to the wall. The ceiling tiles appeared to be soaking up water as well.

What was most heartening, though, was the sight of a dozen or so library staff already busy rolling out plastic sheeting, cutting it to size for the shelf range and pulling it over the shelving. In no time, all potentially affected bookshelves were covered with sheeting!

It turned out that the combination of a long stretch of dry weather, a sudden downpour, aging drains and tree roots conspired to create the ideal conditions for this basement flooding to occur.

\section{Lessons Learned}

Preparedness matters. The library maintains emergency supplies in a garbage can on all six floors of the library, including a roll of plastic sheeting that is stored with the supplies. For this emergency, sheeting was brought from several floors in order to cover the number of shelves necessary to protect the books from potential water damage. Having adequate equipment read-

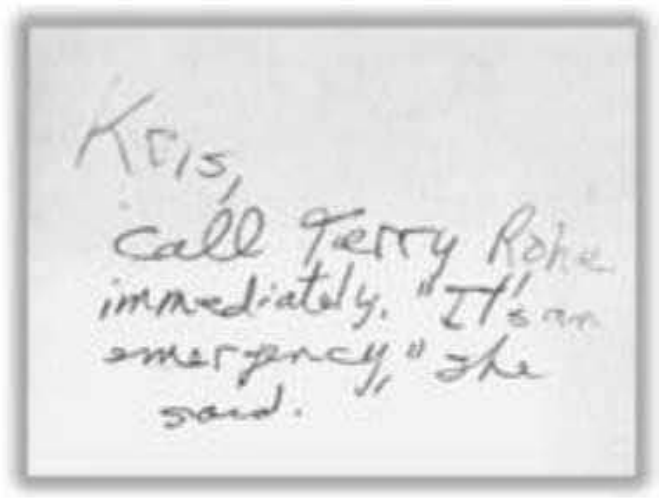

ily accessible to remove the standing water (commercial grade wet vacs), fans, floor dryers, and possibly a dehumidifier is also important.

Library shelving with the four inch gap between the floor and bottom shelf saved books from soaking up water from the floor. It's never a good idea to place library materials directly on the floor-emergencies do happen.

Teamwork is critical to an effective response. Having staff trained in emergency response and knowledgeable of the emergency supplies' locations means your response and recovery can be timely and appropriate.

Basements are inherently problematic locations for collections. There are numerous instances where collections stored in basements have suffered flood water damage - University of Hawai'i at Manoa and Colorado State University are examples of flash flooding that affected hundreds of thousands of volumes (CSU) and thousands of rare maps (UHM). Given time to respond, the University of Iowa was able to move its vulnerable collection from the basement to upper floors and protect it from rising flood waters from heavy rains. $4 s_{5}$ 